\title{
Study regarding the financial stability of commercial banks listed on Bucharest Stock Exchange of CAMELS rating outlook
}

\author{
Balteş Nicolae \\ "Lucian Blaga" University \\ Romania \\ e-mail:baltes_n@yahoo.com \\ Rodean (Cozma) Maria-Daciana \\ "Lucian Blaga" University \\ Romania \\ e-mail:maria.daciana89@yahoo.com
}

Abstract. The study's propose is a theoretical and pragmatic approach of the CAMELS rating as of financial stability analysis tool of commercial banks listed on BSE. The analysis made on the financial statements of the four commercial banks listed on Bucharest Stock Exchange during three financial years showed that the credit risk is their point of vulnerability, having a negative influence on the indicators, that are taken into account in the CAMELS model proposed. The calculation and the analysis of Basel III Agreement indicators are proposed in order to have an attentive monitor of the bank activity revealed that the four credit institutions listed on BSE are not yet fully prepared to implement the requirements of the agreement.

Keywords: CAMEL, financial stability, profitability, capital adequacy, risk sensitivity.

\section{JEL classification: G2, E5}

\section{INTRODUCTION}

The turmoil on the financial markets during 2007-2008, have invalidated a number of paradigms, due to the fact that many large credit institutions with international activities, although they were assigned by rating agencies with lower levels of risk categories faced bankruptcy or last-minute intervention of the state so that they can continue their activity. Thus arose some controversy about the effectiveness of financial ratings as surveillance tools and on the level of trust that was given to this instrument for monitoring and evaluation of the stability of commercial banks in order to avoid an excessive level risk due to asymmetry information. Taking into account the fact that banks must have an appropriate tool to assess their strengths and their vulnerabilities in order to consolidate their capacity to trigger a systemic risk. The negative events that characterize the last period of time and also the changes that occurred in terms of banking legislation determined many researchers to verify the existence of some methodology' model, to introduce new indicators 
or to eliminate the unuseful ones. Furthermore the banks' obligation to implement the new requirements that are imposed by the New Basel III Agreement, corroborated with having a useful tool to monitories the banks' ability to achieve the desired stability, it determine the need of this study.

\section{STATE OF KNOWLEDGE}

The usefulness of early warning tool is required in an attempt to minimize the risks effects that can have on the manifestation of credit institutions. Late 1980s and early 1990s was the first years of studies on bank performance, using mainly two models: the market model (Market - Power MP) and the structural efficiency (Efficiency Structure Model - ES) (Mens and Zouar, 2010).

National Bank of Romania has implemented the system in 1999 and early warning CAMELS rating system, as the CAMEL. In 2001, the system was significantly improved by introducing the analysis of two new indicators: the quality of management and the quality of shareholders. This warning system is rooted in the American one, adopted by the Federal Financial Institution Examination Council on November $13^{\text {th }}$, 1979 and in October 1987 by the National Credit Union Administration. In subsequent years, this system has proven to be a useful tool for monitoring and evaluating the stability of banks. (The United States). Uniform Financial Institutions Rating System, 1997, p.1). According to experts, CAMELS rating system has become an indispensable and concise tool for the authorities, regulators and examiners. (Bar, 2002, page 19).

Some researchers are considering that the traditional CAMELS Systems has several limitations in order to predict bankruptcies, so it needs to be complemented by other indicators. (Rojas-Suarez, 2001). The analysis of the macroeconomic determinants of banks' credit risks represents one of the most used method in the last years, besides the research on traditional balance sheet data. A relevant study made by Chan -Lau in 2006, who starts its research from the review of several-fundamentals-based models (macroeconomic based models, credit scoring models, rating-based models) in order to estimate the EDF's for firms and or industries, and finally to illustrate them with real applications by practitioners and policy making institutions. (Chau-Lau, 2006).

Two Americans reaseachers have demonstrated in 2010 through their studies that CAMELS have a high degree of predictability of US bank failures during the global financial crisis. To conclude this Jordan have used proxies for CAMELS and the multiple discriminant analysis methodology to predict US bank failures during the global financial crisis, while the second one L'opez-Iturriaga use proxies of CAMELS and an artificial neural network for the same purpose. (Jordan et all, 2010, Lopez-Iturriaga et all, 2010).

Essentially this indicator acronym name suggests the main components considered in calculating the composite rating: the capital adequacy $(\mathrm{C})$, the asset quality $(\mathrm{A})$, the quality of shareholder $(\mathrm{A})$, the quality management $(\mathrm{M})$, the profitability $(\mathrm{P})$, the liquidity $(\mathrm{L})$.

The efficiency rating system is reflected in its ability to identify potential problems in financial institutions based on their current financial situations, based on the quantitative and qualitative analysis methods. Studies conducted in 2003 by Jagtiani, Kolari, Lemieux, Shin showed that the operational objective of these early warning systems is to estimate the probability of bankruptcy or rating downgrade using logit/ probit regression or models duration type.

In a study conducted in 2003 and 2004 by researchers Furfine, Upper and Worms, it was shown that the use of rating systems derives from the need to prevent the appearance of the phenomenon of indirect contamination. On eliminating the risk of indirect bank contagion the specialized theory and practice considered as the most appropriate instrument interbank contagion test (Moinescu B., pg 11). 
The bank rating allows credit institutions to identify those showing poor performance, increase their chances of rehabilitation and improved communication with operators supervisory authorities, when the market appears insolvency of a credit institution. CAMELS supervisory system is the most popular model being used and adopted by the central banks of many countries. CAMELS warning system is not used by all the central banks having the aim to supervise. The Fed Bank uses the Risk Bank SEER model and the probability of bank failure or undercapitalization is determined through a probit regression type; FDIC uses SCOR model measuring bank performance deterioration. European Union Countries having a developed economy are using other systems of performance evaluation by supervisors. For example France is using three models: SAABA - early warning system, SIGAL - support system of examinations on site and ORAP - rating system off- site, while Germany is using BAKIS system and Italy - PATROL. (Trenca I., Bolocan D, 2011, page 96-97).

The specialized studies undertaken have shown the ability to identify early indicators used by the emergence of crises. In 2007, Cihak and Schaek demonstrated potential financial stability indicators to explain the crisis occurred and that some indicators are not strictly comparable. Demirgus-Kunt and Detragiache in 1998 through a study, explained that the nonperforming loans rate is an indicator signal on the emergence of systemic problems, while ROE is a tool that is intended to indicate the crisis.

Studies have been undertaken on the stability of credit institutions in many EU countries (Czech Republic, North Cyprus, Romania), Derviz and Podpiera in 2008 emphasized the evolution of indicators of financial stability studies for the top 5 banks in the pre and post privatization period.

It is evident from the acronym bank rating system and early warning used by National Bank of Romania, in the model using a number of indicators that are intended to reflect the stability of banks and to reduce systemic risk so they can ensure the main objective of NBR is the financial stability. The six indicators introduced into the CAMELS model are closely monitorized by the supervisory body:

- on-site when the focus is mainly on quality indicators: the quality of management and the quality of shareholders;

- off-site when the emphasis is focused on quantitative indicators.

CAMELS ratings for the components are subject to periodic updates from inspection activities at the headquarters of banks. (Trenca I and Bolocan D, 2011, page 98). Quantitative components embedded within the CAMELS model are: capital adequacy, asset quality, profitability and liquidity.

Capital adequacy is a very important indicator given that it emphasizes the ability of capital to absorb shocks in close correlation on the one hand provided the macroeconomic environment on the other hand the risk strategy approved by the management of the bank. Adoption of Basel II Agreement and the transition to implementation of the new Basel III, contributed to the development of the definition of the capital adequacy, to studying the interdependencies between moral hazard and prudential requirements imposed by these regulations. Although these requirements have a different role than the strengthening of capital to absorb shocks, they must be sufficiently lenient so that banks can set their own risk profile as the minimum requirements. ( Hellman TF, KC Murdock and JE Stiglitz, 2000). Capital adequacy in the model can be measured by numerous indicators determined taking into account the informations provided by the balance sheet and profit and loss: Core Capital / Weighted Regulatory Risks, Fitch Eligible capital / Weighted Regulatory Risks ; Tangible Common Equity / Tangible Assets ; tangible Common Equity / Total Business Volume, Tier 1 Regulatory Capital Ratio, Total Regulatory Capital Ratio ; Fitch Eligible Capital / Tier 1 Regulatory Capital , Equity / Total Assets, Cash Dividends Paid and Declared / Net Income, Cash Dividends Paid and Declared / Fitch Comprehensive Income , Net Income - Cash Dividends / Total Equity. (Ginevicius R. and A. Podviesko 2010). Given the economic and financial crisis caused an erosion of capital base and ability to cover losses, to improve the quality, consistency and transparency of the capital base was 
necessary to impose a new system of limits for capital items improving disclosure requirements so that the volume of Tier 1 to increase to $6 \%$ (compared to $4 \%$ covered by Basel II) and $4.5 \%$ base funding level (compared to $2 \%$ required by Basel II) .

Asset quality, express the bank resistance to shocks from outside and not regarded as distinct from capital adequacy due to the fact that impairment has a significant impact on the solvency ratio. As indicators by which to determine the quality of assets include: the nonperforming loans rate and the total volume of loans in bank assets.

ROA and ROE are indicators that show the profitability of credit institutions. According to a study made by the researchers of the Monetary Fund (Inci Ötker-Robe and Jiri Podpiera 2010), ROA and ROE reflect the amount of income that a bank can generate taking into account the volume of worthiness of the bank shareholder and total assets.

The bank liquidity is defined as the ability of a credit institution to face its short-term obligations, and to cope with unexpected withdrawals by depositors. In most studies, the liquidity is measured by the indicators: immediate liquidity, effective liquidity and loan / deposit ratio. In terms of liquidity, the new Basel III Agreement imposes new regulations and requirements through two indicators: liquidity coverage requirement (whose goal is to cover liquidity needs on a time horizon of 30 days under a crisis scenario combined) net stable funding indicator (whose objective is to avoid excessive use of short-term financing in times of ample liquidity).

The other two qualitative indicators, the quality of management and the quality of shareholders were included in the model in 2000, having a major bearing in mind that the results are the effects of the relevant decisions of a proper determination of the risk profile and assessing compliance with prudential requirements. Avkiran and Cai (2012) have demonstrated that in assessing the quality of management can be used the following indicators: the share of operating expenses to total assets, interest expense on deposits to total deposits, personnel expenses related to asset and cost-average income.

Based on the concepts studied in-depth by the literature, in this study it was analyzed the stability of four credit institutions listed on BSE, through the mentioned indicators, using MS Excel software:

Table 1

Indicators CAMELS Model

\begin{tabular}{|l|l|}
\hline \multirow{4}{*}{ Capital Adequacy } & Equity/Total assets \\
\cline { 2 - 2 } & Leverage effect \\
\cline { 2 - 2 } & Solvency ratio \\
\hline \multirow{4}{*}{ Asset quality } & Total loans / total assets \\
\cline { 2 - 2 } & Asset growth rate \\
\cline { 2 - 2 } & Loan loss provision / Total Loans \\
\cline { 2 - 2 } & Growth rate of loans \\
\hline \multirow{2}{*}{ Profitability } & ROA \\
\cline { 2 - 2 } & ROE \\
\hline \multirow{2}{*}{ Liquidity } & Loans / deposits \\
\cline { 2 - 2 } & Net Stable Funding Ratio \\
\hline \multirow{2}{*}{ Quality management } & Interest Expenses / deposits \\
\cline { 2 - 2 } & Operating expenses/deposits \\
\hline Sensitivity Risk & the bank assets / total assets of banking system \\
\hline
\end{tabular}

Source: own processing taking into account the literature review. 


\section{EMPIRICAL STUDY REGARDING THE FINANCIAL STABILITY OF COMMERCIAL BANKS LISTED ON BSE}

The datas used in the actual case are taken and processed in the financial statements of the four credit institutions operating on the Romanian banking market, listed on BSE, prepared for the 2011, 2012 and 2013 financial years. Based on the average values of the indicators calculated for these years the bank whose level of the indicator is best placed, will be assigned level 1 , followed the score attributed to other credit institutions to grow ordered from 1 up to 4 .

The first indicator used in the model having the letter "C" - capital adequacy (chart no. 1), requires the calculation of three indicators. The results must determine the level of capitalization of credit institutions and also the capital strength to absorb any shocks. Although one of the indicators (leverage) is not currently approved, knowing only its value will be set differently depending on the size of the credit institution by the end of 2016, it was considered appropriate its introduction into the model to test banks' ability to implement and adopt the new requirements.

\section{Capital Adequacy}

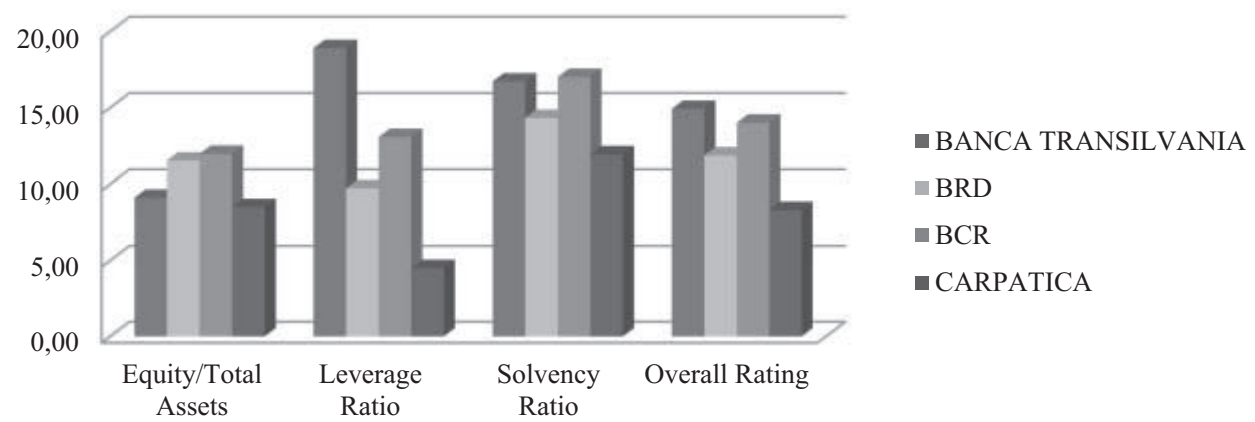

Chart 1. Capital adequacy of credit institutions listed on BSE

Source: own processing of the data of the financial statements of banks listed on BSE

The results lead to the conclusion that in terms of overall rating of Transilvania Bank records that highest score, followed by BCR, BRD, Carpatica Bank. Comparing the average solvency ratio of the 4 banks with the average registered by the entire banking system during the analyzed period, $14.7 \%$ and $15.5 \%$ (2013), BCR and Transilvania Bank obtained an upper result comparing with the average, while the other two being below the level of the banking system. However the four banks recorded a level indicator above $10 \%$ imposed by National Bank of Romania. The high percentage that represents the total loans in total assets shows that impairment of loans (whose trend during the three years under research) raises the issue of capital loss due to the increase in provisions level.

Asset quality is analyzed in terms of three indicators: asset growth rate, the growth rate of loans and the ratio of depreciation adjustments (loan loss provisions) and total loans. Given that $92 \%$ of the national economy is financed by the banking system through credits the significant share of the assets is represented by loans. Years of crisis created serious problems of credit institutions in the loan portfolio taken from at least 
two reasons: a low lending rate and a rising level of nonperforming loans, which led to a worsening of loan quality. The results of the average credit quality analysis of the loans during 2011 and 2013 are summarized in the second table.

Table 2

Analysis of asset quality

\begin{tabular}{|l|c|c|c|c|c|c|c|c|c|c|}
\hline \multirow{2}{*}{ Credit institution } & \multicolumn{2}{|c|}{ Asset growth rate } & \multicolumn{2}{|c|}{$\begin{array}{c}\text { Impairment } \\
\text { losses / total } \\
\text { loans }\end{array}$} & \multicolumn{2}{c|}{$\begin{array}{c}\text { Growth rate of } \\
\text { loans }\end{array}$} & \multicolumn{2}{c|}{$\begin{array}{c}\text { Total loans / total } \\
\text { assets }\end{array}$} & \multicolumn{3}{|c|}{ Overall Rating } \\
\cline { 2 - 13 } & Mean & Rating & Mean & Rating & Mean & Rating & Mean & Rating & Mean & Rating \\
\hline TRANSILV. BANK & 11.08 & 1 & 8.22 & 3 & 11.98 & 2 & 55.07 & 3 & 21.59 & 3 \\
\hline BRD & -1.73 & 3 & 11.75 & 2 & -5.98 & 1 & 67.17 & 1 & 17.80 & 1 \\
\hline BCR & -6.85 & 4 & 5.12 & 1 & 0.92 & 4 & 66.75 & 2 & 16.49 & 4 \\
\hline CARPATICA & 4.04 & 2 & 20.13 & 4 & 7.26 & 3 & 30.02 & 4 & 15.36 & 2 \\
\hline
\end{tabular}

Source: own processing of the data of the financial statements of banks listed on BSE during 2011-2013 using MS Excel system.

Analyzing the results of the above indicators it can be noted that during 2011-2013 there were significant variations in terms of increasing both total assets and loans. In terms of rising asset Transilvania Bank recorded the largest increase, followed by Carpatica Bank, while BCR and BRD showed negative levels of this indicator. Even though Transilvania Bank and Carpatica Bank have positive rates in terms of assets growth, the mean is still affected by the negative evolution of this indicator during 2013, because of the decreasing trend of the loans supply and demand, the lack of trust of the debtors in banking system. The negative level of BRD was maintained in terms of growth rate loans, while the other analyzed banks had positive evolution. Another aspect noted is that although loans have a significant share in total assets, an exception can be identified namely Carpatica Bank whose main asset is the financial investments (56\%). It also notes a trend of depreciation of loan portfolio quality which is one of the major vulnerabilities facing the entire Romanian banking system.

Profitability is a primary indicator in the analysis of business of a credit institution. The most relevant indicators in profitability and used in the model are ROA (Return on Assets) indicator measuring the efficiency of assets to generate profit and ROE (return on equity), indicator that shows the contribution of banks equities to generate profit. The average results obtained by the four Banks studied during the period of the years 2011-2012 are summarized in the chart 2 .

During 2011-2013 the average of ROA and ROE is negative in case of BRD as a result of losses registered by the bank over this period, while Transilvania Bank and Carpatica Bank have significantly improved the level of these indicators. However, the four credit institutions analyzed achieved an average level of the profitability indicators up to the average registered by the Romanian banking system during this period. 


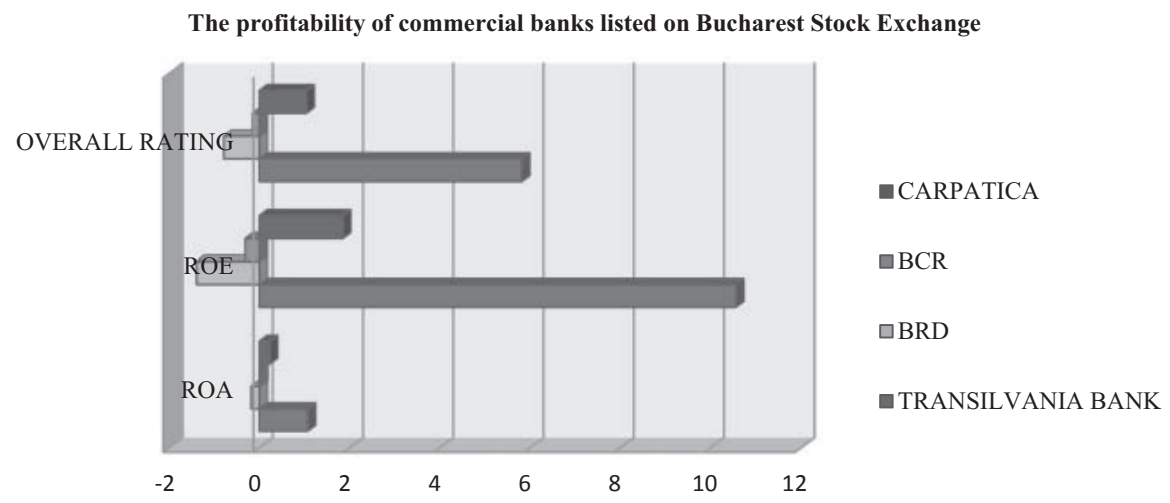

Chart 2. The average profitability of credit institutions

Source: own processing of the data of the financial statements of banks listed on BSE during 2011-2013 using MS Excel system.

In the frame of CAMEL model, the liquidity of the four credit institutions analyzed is assessed based on two indicators: loan / deposit ratio and net stable funding by indicator (NSFR). The inclusion of the second indicator in the model derived from the requirements of the Basel III Agreement, with its implementation. NSFR role is to avoid excessive use of short-term financing in periods of high liquidity. The mean of the indicator calculated for the years 2011 and 2012 are shown in the Table 3.

Table 3

Average Liquidity indicators 2011-2012

\begin{tabular}{|l|c|c|c|c|c|c|}
\hline \multirow{2}{*}{ LIQUIDITY } & \multicolumn{2}{|c|}{ loans / deposits } & \multicolumn{2}{c|}{ Net Stable Funding Ratio } & \multicolumn{2}{c|}{ OVERALL RATING } \\
\cline { 2 - 7 } & Mean & Rating & Mean & Rating & Mean & Rating \\
\hline $\begin{array}{l}\text { TRANSILVANIA } \\
\text { BANK }\end{array}$ & 69.13 & 3 & 1.93 & 2 & 35.53 & 3 \\
\hline BRD & 83.12 & 2 & 0.55 & 4 & 41.84 & 2 \\
\hline BCR & 129.17 & 1 & 0.57 & 3 & 64.87 & 1 \\
\hline CARPATICA & 48.46 & 4 & 6.08 & 1 & 27.27 & 4 \\
\hline
\end{tabular}

Source: own processing of the data of the financial statements of banks listed on BSE during 2011-2013 using MS Excel system.

The average results obtained lead us to conclude that the four credit institutions have the capacity to face its short term obligations, but it must pay attention especially two banks to the maximum net stable funding indicator a ratio that will come into effect with the implementation of Basel III Agreement. It can be seen that there is a slight downward trend in savings attributed to reduced level of passive interest rate. More for BCR level indicator suggests an imbalance between the loans and deposits and an aversion to loans from parent bank as the main source of funding at the expense stimulate saving. Although the liquidity of the BCR register the best level for the years 2011, 2012 and 2013, followed by the BRD, Transilvania Bank and Carpatica Bank. 
Quality of management, although it is an indicator introduced later in calculating of the compound rating has a particular importance due to the fact that the results obtained are due to the quality of decisions taken by the board of the credit institution in terms of strategy, policies and practices, etc.. In the proposed model, the indicator will be assessed by two sub-indicators, namely: interest expenses / deposits and operating expenses / deposits. Deposits with equity and interbank funding are the main sources of funding and to increase profitability, the total interest costs as well as operational should be minimal. The results of data processing are summarized in Table 4.

Table 4

The quality of management

\begin{tabular}{|l|c|c|c|c|c|c|}
\hline \multirow{2}{*}{ Management' Quality } & \multicolumn{2}{|c|}{$\begin{array}{c}\text { interest expenses/de- } \\
\text { posits }\end{array}$} & \multicolumn{2}{c|}{ operating expenses/deposits } & \multicolumn{2}{c|}{ OVERALL RATING } \\
\cline { 2 - 7 } & Mean & Rating & Mean & Rating & \multicolumn{2}{c|}{ Mean } \\
Rating \\
\hline $\begin{array}{l}\text { BANCA TRANSILVA- } \\
\text { NIA }\end{array}$ & 4.15 & 2 & 3.63 & 1 & 3.89 & 2 \\
\hline BRD & 3.49 & 1 & 4.12 & 2 & 3.81 & 1 \\
\hline BCR & 6.61 & 3 & 4.37 & 3 & 5.49 & 3 \\
\hline CARPATICA & 8.51 & 4 & 6.21 & 4 & 7.36 & 4 \\
\hline
\end{tabular}

Source: own processing of the data of the financial statements of banks listed on BSE during 2011-2013 using MS Excel system.

For a high efficiency management, the indicator level must register low values. According to the calculations, a good management is find to BRD, Transilvania Bank, followed by BCR and Carpatica Bank.

Sensitivity to risk, systemic risk that approximates the activity of credit institutions can print the entire system. It is determined as ratio of current credit institution and total bank assets recorded by the banking system (table no. 5).

Table 5

Risk sensitivity of banks listed on BSE

\begin{tabular}{|l|c|c|}
\hline \multirow{2}{*}{ Sensitivity Risk } & \multicolumn{2}{c|}{ the bank assets / total assets of banking system } \\
\cline { 2 - 3 } & Mean & 2 \\
\hline TRANSILVANIA BANK & 7.6 & 3 \\
\hline BRD & 12.41 & 4 \\
\hline BCR & 18.66 & 1 \\
\hline CARPATICA & 1.09 & Rating \\
\hline
\end{tabular}

Source: own processing of the data of the financial statements of banks listed on BSE during 2011-2013 using MS Excel system.

It is observed that BCR has the largest market share, followed by BRD, Transilvania Bank and Carpatica. The fact that BCR has the highest market share is primarily due to the bank's strategy, which in the 
boom years, benefiting from reduced financing costs obtained from the mother bank managed to increase the loan portfolio and thus become the main player in the market in terms of assets.

In order to determine the composite rating assigned to each credit institution, depending on the results it was intended to build a starting average in each indicator presented (chart no. 3).

The composite rating of the four commercial banks listed on BSE

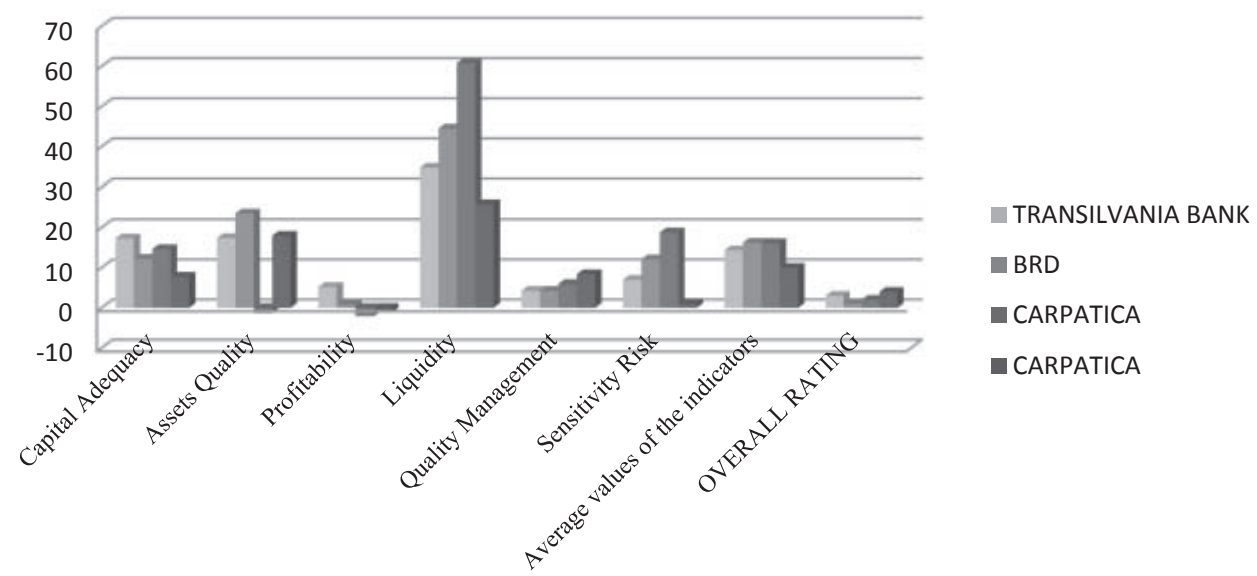

Chart 3. The composite rating of the four commercial banks listed on BSE

Source: own processing of the data of the financial statements of banks listed on BSE during 2011-2013 using MS Excel system.

According to the compound rating, it is clear that in the period 2011-2013, BRD is the best placed credit institution listed on BSE, followed by BCR, Transilvania Bank and Carpatica Bank. However the model results identified the vulnerabilities of the four credit institutions regarding the asset quality and profitability.

\section{CONCLUSIONS}

CAMEL rating is a very useful tool for the assessment of financial stability Romanian commercial banks, while the financial and economic crisis has had an impact on their activities. The research conducted has led us to the conclusion that CAMELS rating system is adequate and likely to identify early shocks.

The results of the actual study have demonstrate the vulnerabilities of credit institutions listed on $\mathrm{Bu}-$ charest Stock Exchange, namely: worsening loan quality, increase insolvent debtors, increased currency risk to depositors, tighter credit conditions. Another conclusion that can be seen refers to the bank's capacity to implement the new requirements that are imposed by the Basel III Agreement, demonstrating that the four banks analyzed are not fully prepared to adopt these modifications. Furthermore these requirements imposed several changes in the structure of the credit institutions' balance sheet in order to be able to adopt the modifications (changes in the assets structure, capital structure, being more attentive on the level of the nonperforming loans and the techniques used in order to reduce them). Significant share of loans in total assets 
in conjunction with the worsening of their quality has diminuated the equity level, and for the moment it is placed above the level required by international regulations for prudential reasons (Cooke Normative: $8 \%$ ) and national (BNR: 10\%). (Baltes Nicolae, 2010, pg 209)

Profitability and liquidity indicators show that the four banks that were analyzed are still vulnerable and not yet fully prepared to implement the new regulations to be imposed by Basel III Agreement.

The results of calculation of risk sensitivity showed a major concentration of the Romanian banking system, BRD and BCR being the main players, together holding over $30 \%$ of the market share, reported on total assets. The final computing rating indicates the performance of foreign management for the commercial banks listed on BSE, showing that their decisions have positively influenced of their stability.

\section{ACKNOWLEDGMENTS}

„This work was supported by the strategic grant POSDRU/159/1.5/S/133255, Project ID 133255 (2014), cofinanced by the European Social Fund within the Sectorial Operational Program Human Resources Development 2007 - 2013."

\section{REFERENCES:}

Avkiran, N. K., Cai, L., (2012), Predicting bank financial distress prior to crises, UQ Business School, The University of Queensland, Australia, Working paper, disponibil: http://www.nzfc.ac.nz/archives/2012/papers/updated/24.pdf

Balteş, N., (2010) - Analiză şi diagnostic financiar, "Lucian Blaga” University Library, Sibiu, p.209

Barr, Richard S. et al. (2002). Evaluating the Productive Efficiency and Performance of U.S. Commercial Banks. Engineering Management, 28(8), p. 19.

Čihák, M., and Schaeck, Klaus., 2007, How Well Do Aggregate Bank Ratios Identify Banking Problems, IMF Working Paper 07/275, (Washington: International Monetary Fund).

Demirgüç-Kunt, A., and E. Detragiache, 1998, The Determinants of Banking Crises in Developing and Developed Countries, Staff Papers, International Monetary Fund, Vol. 45, No. 1, pp. 81-109.

Derviz, A., and J, Podpiera, (2008), Predicting Bank CAMELS and S\&P Ratings: The case of the Czech Republic, Emerging Markets Finance and Trade, vol. 44, no. 1, p. 117-130.

Ginevicius R. ans Podviesko A. (2010). A framework of evaluation of commercial banks, Intellectual Economics 2011, No. 1(9), p. 37-53

Hellman T.F., Murdock K.C., Stiglitz J.E., (2000), Liberalization, Moral Hazard in Banking and Prudential Regulation: Are Capital Requirements Enough?, American Economic Review, American Economic Association, vol. 90 (1), pp. $147-165$

İnci Ötker-Robe, Jiri Podpiera, (2010), The Fundamental Determinants of Credit Default Risk for European Large Complex Financial Institutions, IMF Working Paper, june 2010, pg 11

Jagtiani, J., Kolari, J., Lemieux, C., Shin, H., (2003), Early Warning Models for Bank Supervision: Simpler Could Be Better, Federal Reserve Bank of Chicago, Economic Perspectives Q3

Jorge A.Chan-Lau, "Fundamentals-Based Estimation of EDF: A Survey" IMF,WP/06/149

Jordan, D.J., D. Rice, J. Sanchez, C. Walker, and D.H. Worth (2010). Predicting bank failures: Evidence from 2007 to 2010. Working Paper, available at http://papers.ssrn.com

L'opez-Iturriaga, F., O. L'opez-de-Foronda, and I. Pastor-Sanz (2010). Predicting bankruptcy using neural networks in the current financial crisis: A study of U.S. commercial banks. Working Paper, available at http://papers.ssrn.com. 
Mensi, S.and A., Zouari (2010), Efficient Structure versus Market Power: Theories and Empirical Evidence, International Journal of Economics and Finance, 2 (4), p.151-156.

Moinescu, B., (2007), Early Warning System of CAAMPL Rating Downgrade Events, BNR Studies, available at: http://www.bnro.ro/SearchResult.aspx

Rime B., (1998), Capital Requirements and Bank Behaviour: Empirical Evidence for Switzerland, Swiss National Bank

Rojas-Suarez, L., 2001, "Rating Banks in Emerging Markets: What Credit Agencies Should Learn from Financial Indicators," Institute for International Economics Working Paper, 01-6, May.

Trenca, I., and Bolocan, D. (2011), Performanță și risc în bănci, Casa Cărții de Știință Library, Cluj Napoca, 2011, p 96-97.

Basel III Agreement, available online at: www.bis.org

Romanian Commercial Bank (RCB), Annual Report of RCB Bank during 2011-2013, available online at: www.bcr.ro BRD, Annual Report of BRD Bank during 2011-2013, available online at: www.brd.ro

Transilvania Bank, Annual Report of Transilvania Bank during 2011-2013, available online at: www.bancatransilvania.ro

Carpatica Bank, Annual Report of Carpatica Bank during 2011-2013, available online at: www.carpatica.ro

BNR, Monthly Bulletin no. 12/2012, available online at: http://bnr.ro/Publicatii-periodice-204.aspx

BNR, Monthly Bulletin no. 12/2013, available online at: http://bnr.ro/Publicatii-periodice-204.aspx 